\title{
Magnesite soapstone in use of fire chamber constructions: composition and structure adaptation
}

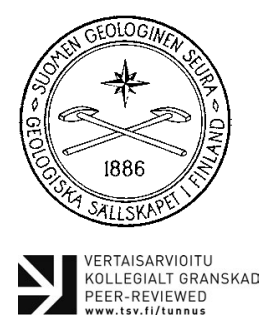

PEER-REVIEWED
www.tsv.fi/tunnus

\author{
Anne Huhta ${ }^{*}$, Pekka Tuisku ${ }^{1}$, Tonci Balic-Zunic ${ }^{2}$ \\ AND AULIS KäRKI ${ }^{3}$ \\ ${ }^{1}$ Oulu Mining School, University of Oulu, P.O. Box 3000, 90014 University of Oulu, \\ Finland \\ ${ }^{2}$ Department of Geosciences and Natural Resource Management, University of \\ Copenhagen, Oster Voldgade 10, DK-1350 Copenhagen K \\ ${ }^{3}$ Kivitieto Oy, Teknologiantie 1, 90590 Oulu, Finland
}

\begin{abstract}
The Finnish soapstone industry has found through practical experience that the surface of the magnesite soapstone used in fire chambers and funnels hardens over time. We have studied a magnesite soapstone used in a fireplace continuously for 60 years. The mineralogical changes, that took place during heating and subsequent cooling of the fireplace have been investigated with electron probe microanalyzer and X-ray diffractometer to find an explanation, what kind of reactions caused the hardening. We found that ferromagnesite has been altered to pseudomorphic aggregates composed of ferropericlase and magnesioferrite in the nearest $\sim 30 \mathrm{~mm}$ from the surface exposed to fire. Iron has been mobilized in the uppermost $3 \mathrm{~mm}$, enriched in the rims, and depleted from the cores of the ferropericlase aggregates. Magnesioferrite occurs preferably in the fire chamber side of the aggregates in the uppermost $0.20 \mathrm{~mm}$. Talc rims are altered to forsterite and/or enstatite in the reaction with ferromagnesite or its alteration products in the uppermost $\sim 1 \mathrm{~mm}$. In addition, wood combustion gases caused considerable enrichment of zinc and potassium in the chamber surface rock to the depth on $0.20 \mathrm{~mm}$ and $3 \mathrm{~mm}$, respectively. The enrichment occurred by crystallization of $\mathrm{Zn}$ bearing ferropericlase and magnesioferrite and by crystallization of $\mathrm{K}$ bearing sheet silicates.
\end{abstract}

Keywords: soapstone, talc, magnesite, periclase, magnesioferrite, decarbonation, dehydroxylation, fireplace, construction stone

*Corresponding author (e-mail: anne.huhta@oulu.fi)

Editorial handling: Ferenc Molnár (ferenc.molnar@gtk.fi) 


\section{Introduction}

Since the beginning of the civilization, heat endurance of talc-carbonate rocks has been broadly known. They have been used as a material for cooking pots and vessels (Storemyr, 2004). Making of soapstone utility artifacts continued through the Middle Ages, and during that period soapstone was starting to be used as a building material (Storemyr $\&$ Heldal, 2002). Nowadays, capacity to withstand constant exposures to thermal shock of a certain types of soapstone allows industrial construction of fireplaces and ovens that are both highly durable and environmentally friendly.

According to the proposal of Huhta \& Kärki (2018), soapstone should contain 35-75 vol.\% talc, providing exceptional softness and easy processing. In addition to talc and carbonate, soapstone can include other magnesium-rich minerals such as serpentine, olivine, chlorite, amphibole, oxides and relicts of $\mathrm{Mg}$-rich silicates. Because of this natural mineral variation, dozens of different soapstone types exist. Hence, thermal properties of these types differ from each other depending on their mineral composition and structure. Only certain mineral compositions together with the favorable structure makes soapstone highly durable in thermal stress (Huhta et al., 2016).

In Finland, talc-carbonate rocks, which in this study have been classified as magnesite soapstone after Huhta \& Kärki (2018), are being widely used as a material in fireplace constructions. Thermal properties of these rocks are ideal for the material used in the walls of fire chambers and funnels.

Because of decades of experience, soapstone industry has learned that the surfaces of the magnesite soapstone used as a construction material in walls of the hottest parts of fireplaces become harder and the structure of the rocks strengthens over the time. Periclase formation is the most obvious change that occurs on the surface of rocks in fire chamber walls. However, it does not produce these highly durable end- products alone. Manufacturing a fireplace solely of magnesite soapstone reduces production costs, hence there is no need for industrial materials protecting the fire chamber wall rocks from high temperatures. Furthermore, accurately selected magnesite soapstone with appropriate structure allows the use of higher temperatures, that leads, via lower particulate emission, to more efficient and environmentally friendly fireplaces. In addition, the thermal conductivity of this fine grained and weakly foliated magnesite soapstone is significantly higher than different industrial materials or soapstone types with thermally unsuitable attributes. In fact, thermal conductivity of magnesite soapstone is twice as high parallel to the schistosity of the rock, compared perpendicular to it (Gehör \& Kärki, 1996). Building the fireplace, the rocks are placed so that thermal conductivity of them is optimal. The schistose structure enables the rapid inner section warming (i.e. heat conducts parallel to the schistosity) and slow heat conduction (i.e. heat conducts perpendicular to the schistosity) from the outer surfaces of the fireplace to indoor air. Hence, the magnesite soapstone fireplace stays warm longer, resulting in more efficient use of bioenergy.

The aim of this study is to describe what kind of mineral alteration in addition to the periclase formation causes magnesite soapstone to harden along with aging. The mineralogical changes of the magnesite soapstone subjected to alternating conditions of temperature and humidity in the fire chamber for over 60 years have been examined using petrographic observations along with electron microprobe and XRD studies.

\section{Samples}

The samples studied in this paper were collected from the fireplace construction, which has been in use over 60 years. The oven material was quarried from the Nunnanlahden Uuni mine (63' $10^{\prime} 20.6^{\prime \prime} \mathrm{N}$ $29^{\circ} 26^{\prime} 35.4^{\prime \prime} \mathrm{E}$ ), one of the four soapstone quarries 
Table 1. Median talc and magnesite compositions (wt.\%) from magnesite soapstones (Kärki et al., 2013).

\begin{tabular}{lccccc}
\hline & $\mathbf{S i O}_{\mathbf{2}}$ & $\mathbf{F e O}$ & $\mathbf{M g O}$ & $\mathbf{C O}_{\mathbf{2}}$ & $\mathbf{H}_{\mathbf{2}} \mathbf{0}$ \\
\hline Tlc & 62.3 & 2.1 & 30.7 & n.d. & 4.9 \\
Mgs & n.d. & 8.3 & 40.4 & 51.3 & n.d. \\
\hline
\end{tabular}

n.d. $=$ not determined

Table 2. Alteration zones and their distances from the surface of the sample.

\begin{tabular}{cccc}
\hline Zone & Distance & Table & Figure \\
\hline 1 & $>30 \mathrm{~mm}$ & 3,4 & $2 \mathrm{~A}, 2 \mathrm{~B}$ \\
2 & $30-3 \mathrm{~mm}$ & 3,4 & $3 \mathrm{~B}$ \\
3 & $3-0.9 \mathrm{~mm}$ & 3,4 & $3 \mathrm{C}$ \\
4 & $0.9-0.5 \mathrm{~mm}$ & 3,4 & $3 \mathrm{D}, 3 \mathrm{E}$ \\
5 & $0.5-0.2 \mathrm{~mm}$ & 3,4 & - \\
6 & $0.2 \mathrm{~mm} \rightarrow$ surface & 3,4 & $3 \mathrm{~F}, 4 \mathrm{~A}, 4 \mathrm{~B}$ \\
\hline
\end{tabular}

in Northern Karelia. Table 1 shows median talc and magnesite compositions of several fresh magnesite soapstones from the area (Kärki et al., 2013).

All samples studied here represent the same block from the inner surface of the fire chamber wall. Two thin sections were prepared. One is from the altered surface of the fire chamber wall and for the reference, another is from fresh part of the sample $15 \mathrm{~cm}$ from the chamber surface. The thin sections were cut vertically starting from the altered surface of the fire chamber going deeper towards the unaltered rock. Three powder samples were prepared for X-ray Diffraction (XRD) study from the same samples as the thin sections. The first was collected from the unaltered magnesite soapstone $15 \mathrm{~cm}$ from the chamber surface, the second from altered rock, at 20-25 mm depth and the third from the most extensively altered zone at the fire chamber surface at zones 3-6 (Table 2, Fig. 1).

\section{Analytical methods}

The thin sections were examined using a petrographic microscope, in transmitted and reflective light, to study the mineralogical composition and microstructures. Further textural study was made by Zeiss Ultra Plus field emission scanning electron microscope imaging and chemical compositions of the mineral phases were determined by wavelength dispersive X-ray spectroscopy (WDS) using Jeol JXA-8200 electron probe microanalyzer $(15 \mathrm{kV}$ accelerating voltage, $10 \mathrm{nA}$ beam current, probe size $\leq 5 \mu \mathrm{m})$ at the Center of Microscopy and Nanotechnology (CMNT), University of Oulu.

The D8ADVANCE Bruker-AXS powder diffractometer with the primary $\mathrm{Ge}_{111}$ monochromator and the LinxEye silicon strip detector in reflection geometry (at the Department of Geosciences and Natural Resource Management, University of Copenhagen) was used for X-ray diffraction measurement of samples. The used radiation was from a Cu-tube (wavelength $1.54059 \AA$ A). The samples were mounted in metal holders with circular indentations $(25 \mathrm{~mm}$ in diameter, $2 \mathrm{~mm}$ depth) and measured in the range $2^{\circ}$ to $90^{\circ} 2 \theta$, with measurement steps of $0.02^{\circ}$ and measuring time of $4 \mathrm{~s}$ per step. The mineral quantification was done by the Rietveld method (Topas V4 program, Bruker-AXS product). 


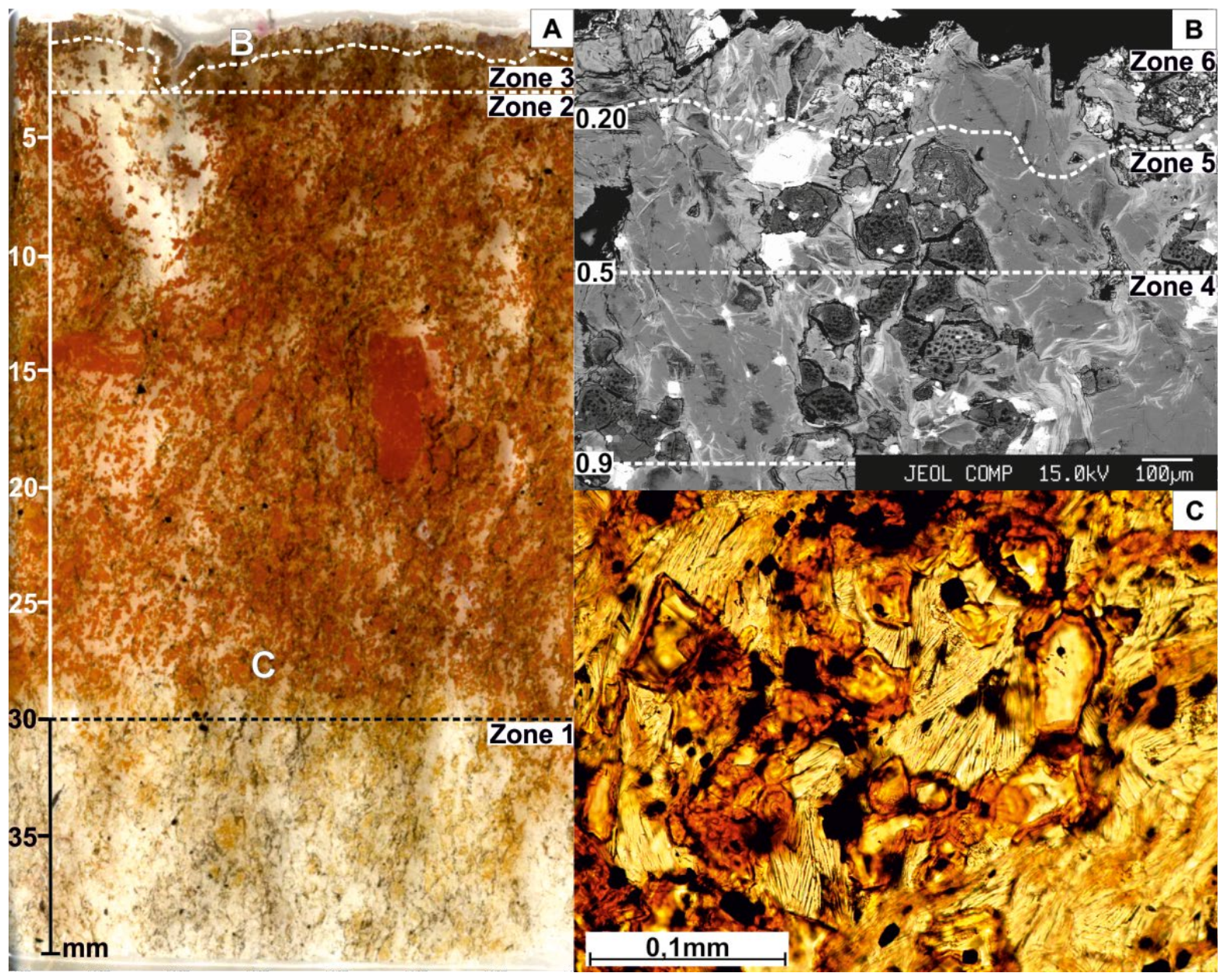

Figure 1. a) A gradually decomposed and altered magnesite soapstone from the fire camber wall of the fireplace studied here. Micrograph of a thin section made from chamber surface to $40 \mathrm{~mm}$ in depth, with the alteration zones 1-6. Letters B and C indicate the locations of adjacent images. b) BSE-image showing different degrees of alteration in magnesite soapstone. Rugged mass surrounds altered magnesite occurring especially on the surface side of the grains. c) Polarizing microscope micrograph of the decomposed and altered magnesite rims $28 \mathrm{~mm}$ from the surface of the sample. Dashed lines indicate zone borders. They follow the rugged form of the sample on the surface of the rock. Straight border lines are based on the data from the microanalyses.

\section{Results}

\subsection{Petrography and mineral chemistry}

From the macroscopic and transmitted light microscopic observations, it is evident that the magnesite grains of the soapstone have been turned to reddish brown pseudomorphs to the depth of $28 \mathrm{~mm}$ from the chamber surface (Fig. 1a). At the outermost $3 \mathrm{~mm}$, where fire and combustion gases have had the most intensive effect on the rock, pseudomorphs are dark brown. With BSE-imaging (Fig. 1b), different degrees of alteration can be observed from $0.25 \mathrm{~mm}$ depth towards the surface of the sample. The most intensive alteration is seen at the surface, going approx. $0.1 \mathrm{~mm}$ into the rock. There, magnesite pseudomorphs are surrounded by grayish and rugged mass, which was not identified in transmitted light. The mass formed especially on 
the fire chamber side of the decomposed magnesite grains (Fig. 1b). Going away from the chamber surface, thickness of the magnesite-surrounding mass and overall alteration gradually decrease until they completely disappear. Magnesite shows only thin alteration rims at the depth of $30 \mathrm{~mm}$ (Fig. 1c). By microscopic and electron probe study, six zones from the unaltered soapstone to the most altered one at the chamber wall were recognized.

\section{Zone 1, depth $>30 \mathrm{~mm}$}

Zone 1 represents the fresh, unaltered rock. It is finegrained with moderate mylonitic foliation revealed by orientation of interlayered talc and chlorite. Magnetite occurs mainly with chlorite as euhedral grains forming thin bands. Ferromagnesite grains are nearly equidimensional with an average grain size of $0.4 \mathrm{~mm}$ and occur often as polycrystalline aggregates. A polished section was made $15 \mathrm{~cm}$ from the surface, and the mineral compositions (WDS) are provided in Electronic Appendix A. Talc contains around 2 wt.\% $\mathrm{FeO}^{\text {tot }}$ and occurs very closely associated with chlorite (Fig. 2a). Ironcontaining magnesite shows enrichment in Fe in the core (Fig. 2b). Magnetite and chlorite are chromebearing and their $\mathrm{Cr}_{2} \mathrm{O}_{3}$ contents are 7.5 wt. $\%$ and $2.4 \mathrm{wt} . \%$ in average, respectively. Magnetite shows also low contents of $\mathrm{Mg}$ and $\mathrm{Ni}$.

\section{Zone 2, depth 30-3 mm}

At $30 \mathrm{~mm}$ depth only few of the magnesite grains have brownish tint, whereas most of them are preserved unaltered. Figure $3 \mathrm{~b}$ represents zone 2 at a depth of $20 \mathrm{~mm}$ from the surface. Concentric zonal decomposition with cracks of ferromagnesite to ferropericlase is characteristic for this level, whereas other mineral phases are still unaltered. Ferropericlase shows large variation in composition, from $\mathrm{Mg}_{0.97} \mathrm{Fe}_{0.03} \mathrm{O}$ to $\mathrm{Mg}_{0.75} \mathrm{Fe}_{0.25} \mathrm{O}$. There is some variation in the composition of chlorite (Electronic Appendix A).

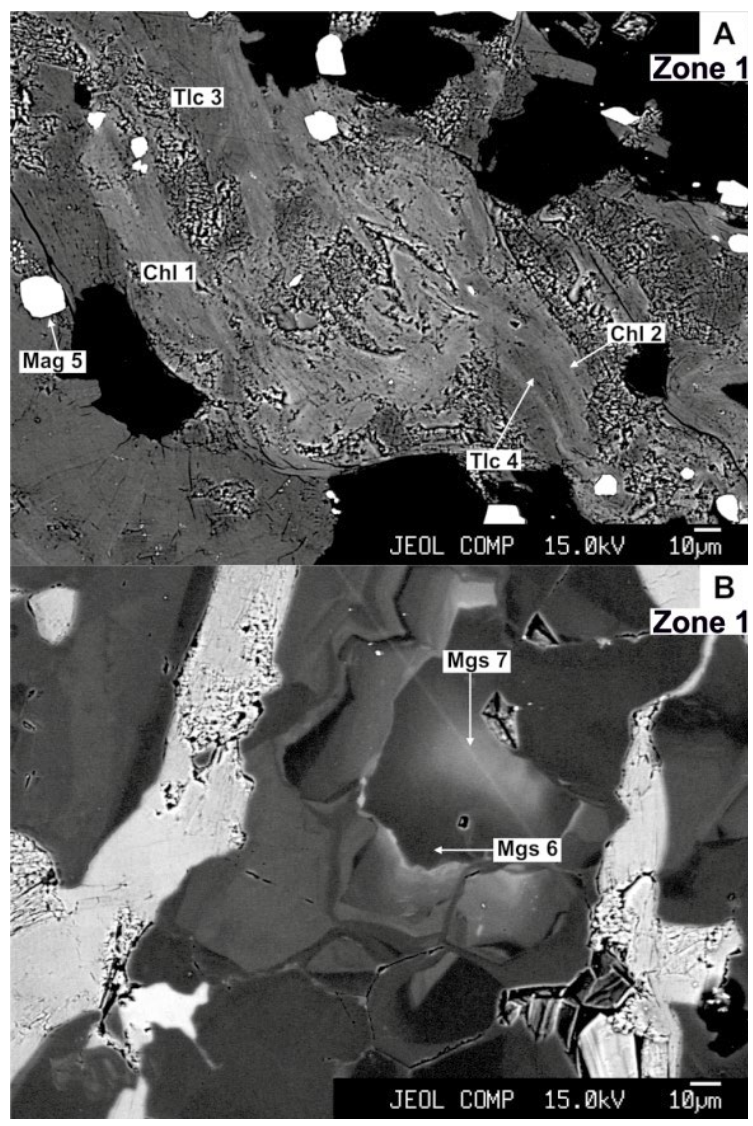

Figure 2. a) \& b). BSE images of the fresh unaltered magnesite soapstone (zone 1). Chl = chlorite, Mgs $=$ magnesite, $\mathrm{Mag}=$ magnetite, $\mathrm{Tlc}=$ talc. Numbers after mineral abbreviations indicate analysis numbers presented in Electronic Appendix A.

\section{Zone 3, depth 3-0.9 mm}

Further changes have occurred at a depth of $3 \mathrm{~mm}$ (Fig. 3c, Electronic Appendix A). Ferropericlase cores contain approx. $14 \mathrm{wt} . \%$ and the rims approx. 23 wt. $\% \mathrm{FeO}^{\text {tot }}$. The zonal texture has almost completely disappeared by removal of concentric cracks, most probably due to recrystallization. Microcracking occurs in and around some grains with brucite often forming inside them. Talc has not been altered. However, chlorite has increased contents of $\mathrm{SiO}_{2}$ (approx. 40 wt.\%) and $\mathrm{K}_{2} \mathrm{O}$ (avg. $3.8 \mathrm{wt} . \%)$ obviously undergoing a transformation. It is also noteworthy that sulfur has entered the rock, especially into rims of ferropericlase at this 
level. There is also sulfur in brucite, usually less than 1 wt.\%. Magnetite also starts to show impurities $\left(\mathrm{SiO}_{2}\right)$ and a small increase in $\mathrm{MgO}$ content.

\section{Zone 4, depth $-0.9-0.5 \mathrm{~mm}$}

A general view from the surface of the fire chamber wall rock through zones $4-6$ is seen in Fig. 3a. Iron content is very low in the cores of former magnesite grains in zone 4 , now a porous periclase with less than 3 wt.\% FeO ${ }^{\text {tot }}$ (Fig. 3d, Electronic Appendix A.). However, the iron content of the rims of the periclase aggregates is quite high, 17-20 wt.\%, suggesting a different mineralogical composition. Brucite surrounds and penetrates the aggregates. Talc is otherwise unchanged, but the rims are transformed to a substance with 51 wt. $\% \mathrm{SiO}_{2}$ and 42 wt. $\% \mathrm{MgO}$ with approx. 1 wt. $\% \mathrm{~K}_{2} \mathrm{O}$ and 1.8 wt. $\% \mathrm{SO}_{3}$. The $\mathrm{SiO}_{2}: \mathrm{MgO}$ ratio shows a loss of $\mathrm{SiO}_{2}$ and enrichment in $\mathrm{MgO}$ and corresponds forsterite. Figure 3d shows these rims in a lighter tone of gray. Pseudomorph after chlorite contains 5-6 wt.\% K $\mathrm{K}_{2}$. Magnetite contains approx. 79 wt.\% $\mathrm{FeO}^{\text {tot }}$ and $0.3 \mathrm{wt} . \% \mathrm{SiO}_{2}$ at this level.

\section{Zone 5, depth $-0.5-0.20 \mathrm{~mm}$}

Close to the surface $(0.5 \mathrm{~mm}$ in depth) iron content of "ferropericlase" varies between 12.5-20.5 wt.\% (Fig. 3e. Electronic Appendix A). The highest contents are found in the rims of the aggregates. Pseudomorph after chlorite has locally up to $8 \mathrm{wt}$.\% $\mathrm{K}_{2} \mathrm{O}$. However, based on XRD measurements it still has the structure of chlorite.

\section{Zone 6, depth $-0.20 \mathrm{~mm}$ to surface}

Transformed chlorite next to magnetite contains 18.5 wt. $\% \mathrm{FeO}^{\text {tot }}$ and almost 8 wt. $\% \mathrm{~K}_{2} \mathrm{O}$. Talc rims have altered to the above-mentioned substance (zone 4). The alteration rim is 20 to $30 \mu \mathrm{m}$ wide and the alteration has also proceeded to cores along cleavage planes. However, a lot of unaltered talc has been preserved in the inner parts of the grains. Centers of the pseudomorphs after ferromagnesite are still ferropericlase, with relatively high $\mathrm{FeO}^{\text {tot }}$ content (10-15 wt.\%) (Fig. 3f). A distinct phase with magnesite composition can be observed containing 16-18.5 wt.\% $\mathrm{MgO}, 39-47$ wt.\% $\mathrm{Fe}_{2} \mathrm{O}_{3}$ (as recalculated from 35-42 wt.\% $\mathrm{FeO}^{\text {tot }}$ ) and up to $8 \mathrm{wt} . \% \mathrm{ZnO}$ (Electronic Appendix A). It shows in the BSE-image as white spots especially on the chamber surface side of ferropericlase aggregates (Fig. 3f). In addition to magnesioferrite, high $\mathrm{ZnO}$ is found in serpentine, in alteration product of talc rims (approx. $1.5 \mathrm{wt} . \%$ ) and in ferropericlase (approx. 5 wt.\%). Figure 4a provides closer view to the surface area. Magnetite grains are often partly depleted in iron (Fig. 4a and Electronic Appendix A). A new magnesium-silicate phase has formed between talc and ferropericlase in the region from surface to $0.06 \mathrm{~mm}$ of depth (Fig. 4c). It contains approx. 32 wt. $\% \mathrm{SiO}_{2}$ and approx. $33 \mathrm{wt} . \% \mathrm{MgO}$. In addition, it has less than 10 wt. $\% \mathrm{FeO}^{\text {tot }}$ and approx. 2 wt.\% $\mathrm{ZnO}$ (Electronic Appendix A), but with low total due to difficulties in obtaining good analysis from this spongy material. According to cation ratios, this phase is most probably a serpentine group mineral.

\subsection{X-Ray Diffraction}

The XRD patterns are shown in Figs. 5-7. The powder diffraction pattern of fresh unaltered sample (Fig. 5) differ substantially from the patterns of two samples (Figs. 6 and 7), which have been exposed to high temperatures. Table 3 shows the modal mineral compositions determined by XRD.

Disappearance of magnesite in zone 2 and its replacement by mainly magnesioferrite and periclase is consistent with the BSE-imaging and microprobe analyses. Variations in brucite content corresponds fully with the EPMA-results since no brucite was detected right near the surface (Electronic Appendix A). It appears that talc has partly altered in zones $2-6$, since talc content in the fresh magnesite soapstone is approx. 60 vol. $\%$ and in the altered zones significantly lower. The amount of talc stays almost equal in both decomposed samples. Findings concern grain size of talc are 


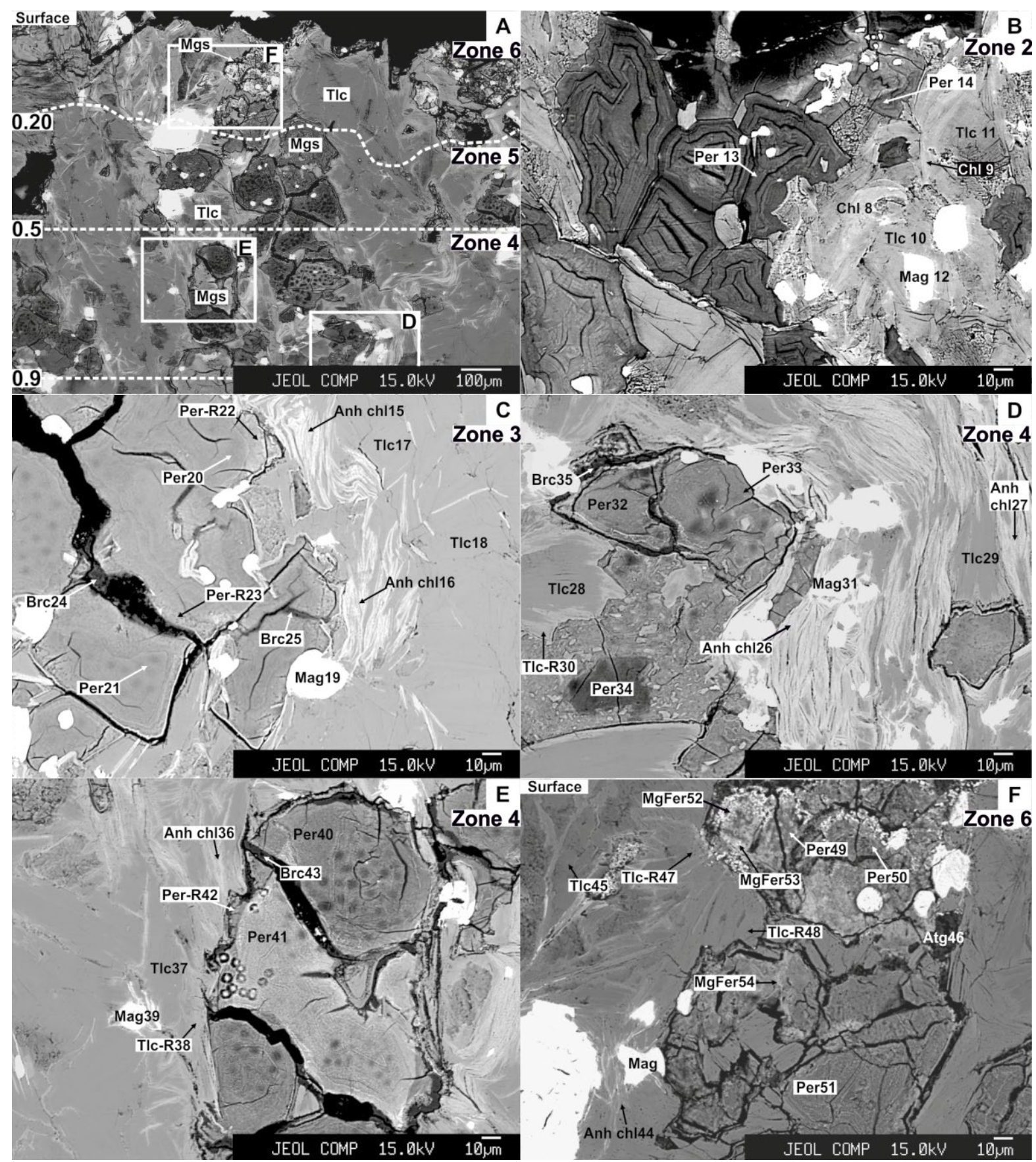

Figure 3. BSE images of the thin section from the decomposed magnesite soapstone. a) A general view from the fire chamber surface. White boxes indicate the locations of images d-f. Dashed lines show zones 4, 5 and 6 . b) Zone 2, 30-3 mm from the surface. c) Zone 3, $3 \mathrm{~mm}$ from the surface. d) Zone 4, 0.9-0.7 mm from the surface. e) Zone 4, 0.7-0.5 mm from the surface. f) Zone 6, from $0.2 \mathrm{~mm}$ to surface. Abbreviations in all figures: Brc $=$ brucite, Chl = chlorite, Per = periclase, Per-R = periclase-rim, Srp = serpentine, Mag = magnetite, MgFer = magnesioferrite, Mgs $=$ pseudomorphs after magnesite, Anh chl = anhydrous chlorite, Tlc $=$ talc, Tlc- $\mathrm{R}=$ talc rim. Numbers after mineral abbreviations indicate analysis numbers presented in Electronic Appendix A. 


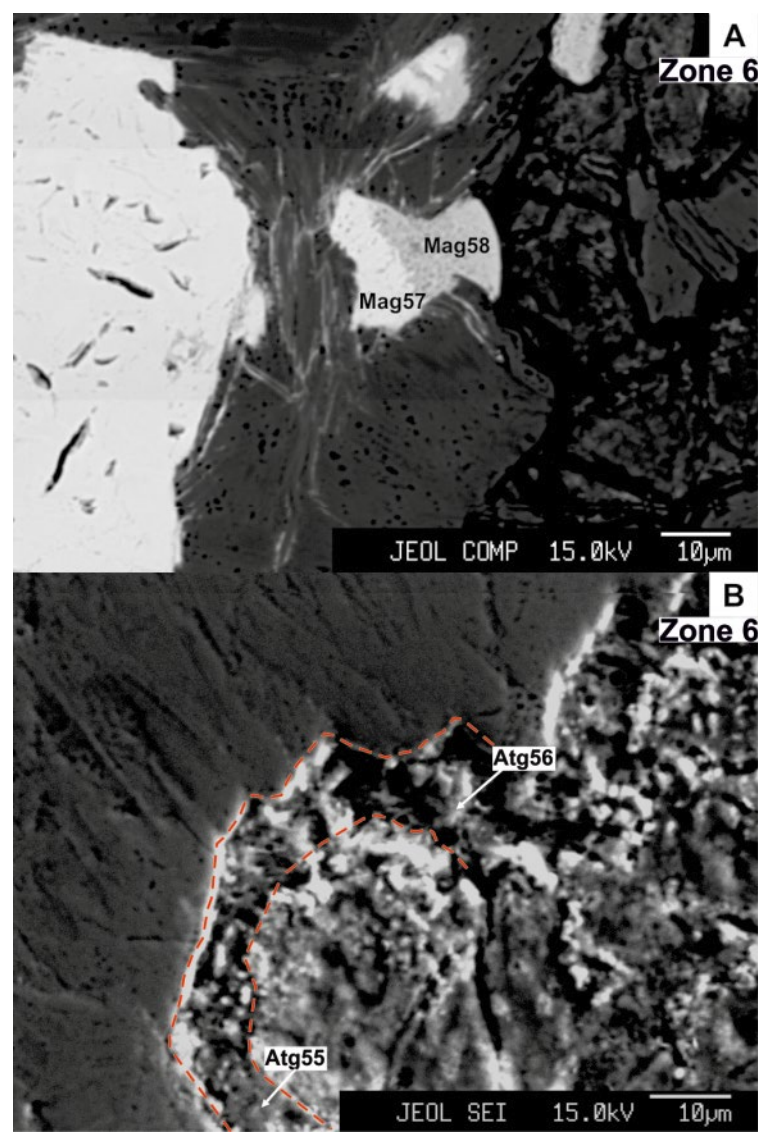

Figure 4. Detailed BSE images of the most altered zone 6 from the fire chamber surface a) Magnetite grain partly depleted in iron and enriched in magnesium and zinc. b) A new magnesium-silicate phase antigorite from the rim of a pseudomorph after magnesite. Numbers after mineral abbreviations indicate analysis numbers presented in Electronic Appendix A.

consistent with Germans` (2010) sintering related grain growth studies. Figures 6 and 7 indicate, that the average crystallite size of talc is significantly larger in the surface layer than in deeper levels.

\section{Discussion}

The chemical compositions of the minerals in the fresh part (zone 1) (Electronic Appendix A, Fig. 2) are similar to typical composition of rocks in Nunnanlahti greenstone belt (Huhta et al., 2016).
The zoning in some magnesites, is due to approx. 1,8 wt.\% variation in $\mathrm{FeO}^{\text {tot }}$ content (Fig. 2 b). Talc is quite close to ideal composition and chlorite can be classified as clinochlore. Talc and chlorite often occur in parallel growth (Beaufort et al., 2015). From this base composition, the decomposition and alteration of minerals due to conditions in fire chamber and funnel have occurred gradually. However, as shown in the back scattered electron image (Fig. 3a), especially the center of talc has been well preserved even near the surface and magnesite appears to be the only phase that has disappeared thoroughly there. Starting from the zone 2, ironbearing magnesite can be regarded as decomposing to ferropericlase according to $(\mathrm{Mg}, \mathrm{Fe}) \mathrm{CO}_{3} \rightarrow$ $(\mathrm{Mg}, \mathrm{Fe}) \mathrm{O}+\mathrm{CO}_{2}$. (Figs. 1a and $3 \mathrm{~b}$ ) However, due to the instability of the periclase-wüstite solid solution, the alteration of magnesite and formation of its decomposition product has probably been a multi-stage process resulting in a complex mixture of magnesium oxide, iron oxide and $(\mathrm{Mg}, \mathrm{Fe})$ hydroxide. This will be considered more carefully later in the discussion.

Chlorite shows significant changes and variation in composition from the zone 3 towards the surface, suggesting a change to another phyllosilicate. However, the XRD pattern shows only minor change without loss of the $14 \AA$ basal spacing. Talc shows signs of decomposition at the rims and along the weakness planes while it remains unaltered in the core part.

\subsection{Reactions of magnesite and talc}

According to thermodynamic data of Holland \& Powell (1998), forsterite forms at ambient pressure around $270{ }^{\circ} \mathrm{C}$ from a reaction between talc and magnesite while enstatite may begin to form at around $350{ }^{\circ} \mathrm{C}$ together with forsterite. It is probable, that these reactions have started before the breakdown of magnesite to periclase at ca. $410{ }^{\circ} \mathrm{C}$ and probably were enhanced during the decarbonatization of magnesite. Resulting this, narrow alteration rim is observed in talc especially in 


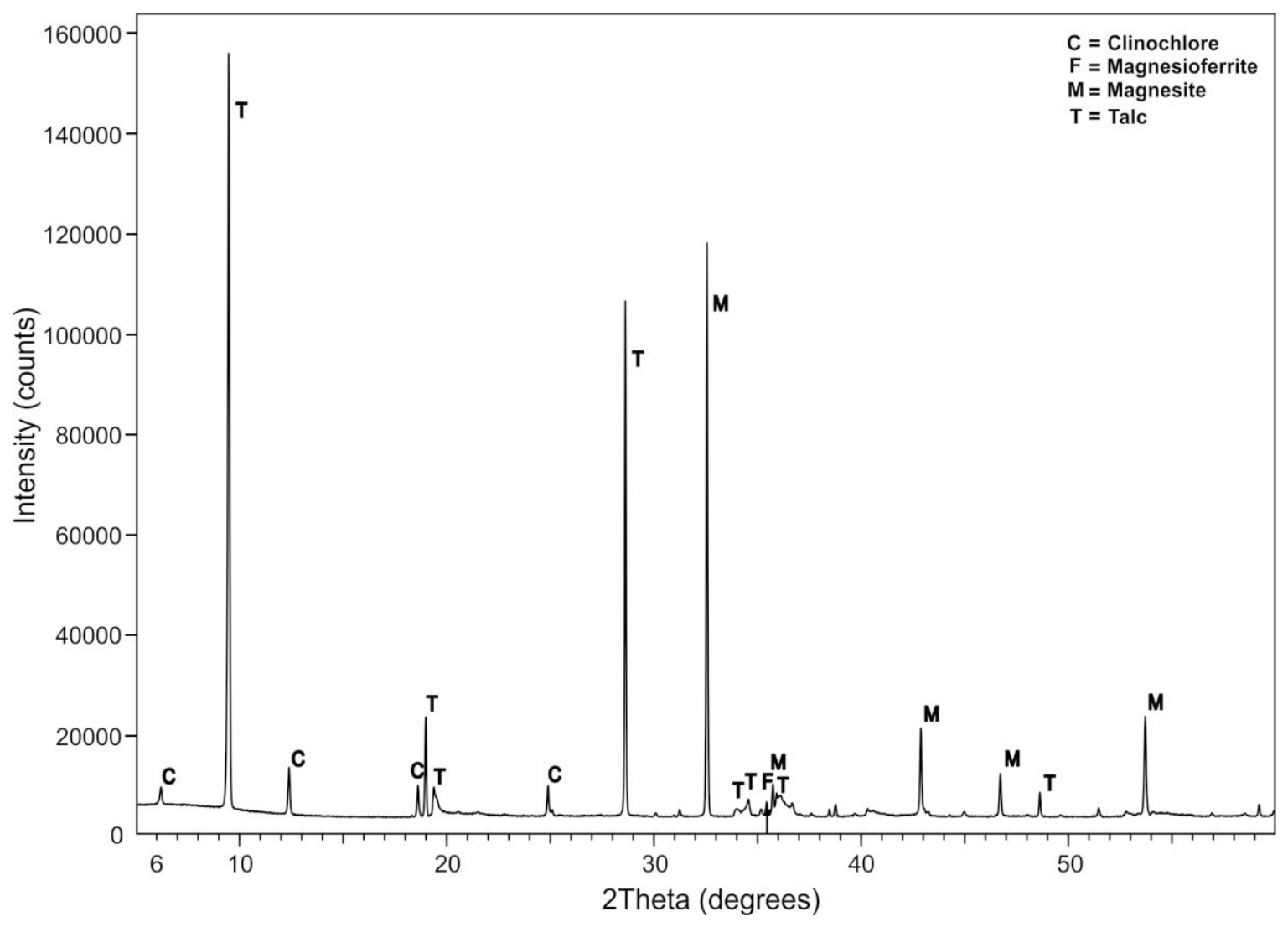

Figure 5. X-ray diffraction pattern of fresh, unaltered magnesite soapstone.

Table 3. Modal composition (wt.\%) of fresh and altered magnesite soapstone determined by XRD.

\begin{tabular}{cccc}
\hline Zone 1 & $\begin{array}{c}\text { Zone 2 } \\
(15 \mathrm{~cm})\end{array}$ & $(20-25 \mathrm{~mm})$ & $\begin{array}{c}\text { Zones 3-6 } \\
\text { (Surface) }\end{array}$ \\
Mgs & 60 & 47.5 & 49.5 \\
Chl & 34 & n.d. & n.d. \\
MgFer & 5 & 8 & 8.5 \\
Brc & 1 & 9.5 & 9 \\
Per & n.d. & 30 & 23.5 \\
Hem & n.d. & 3 & 6 \\
Qtz & n.d. & 2 & 2 \\
En & n.d. & n.d. & 1.5 \\
\hline
\end{tabular}




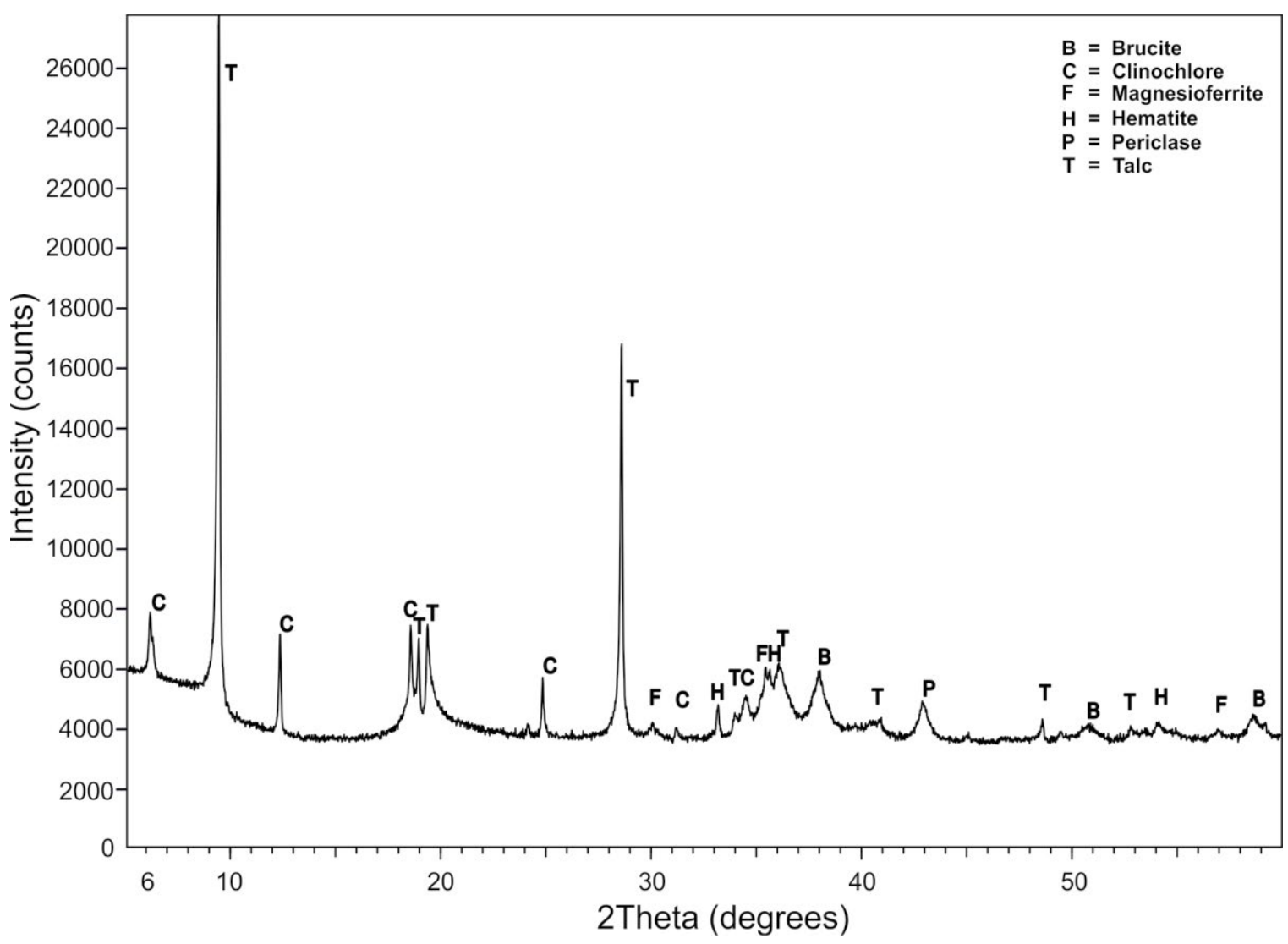

Figure 6. X-ray diffraction pattern of decomposed magnesite soapstone $20-25 \mathrm{~mm}$ from the surface.

the contact zone of altered magnesite (Fig. 3a, $\mathrm{d}$ and e). In addition, analytical data suggests that some enstatite or even forsterite was formed in the rims of talc (Electronic Appendix A). It is also apparent, that the alteration has been most intense in zone 6 immediately at the fire chamber surface. According to XRD-data, some quartz occurs in this zone. It could be derived from breakdown of talc to enstatite and quartz, but from textural point of view the most intensive alteration of talc is the reaction with ferromagnesite.

\subsection{Reactions involving $\mathrm{FeO}, \mathrm{MgO}$ and $\mathrm{SiO}_{2}$ and their mobilization}

Significant changes in iron and magnesium distribution starts to show in zone 3 (Fig. 3c, Electronic Appendix A). Due to regular high- temperature periods, iron has been enriched in the rims of ferropericlase aggregates while in the core the $\mathrm{Mg} / \mathrm{Fe}$-ratio has remained higher and closer to that of unaltered ferromagnesite of zone 2 . The $\mathrm{Mg} / \mathrm{Fe}$-zoning is observed to begin in the deepest $(28 \mathrm{~mm})$ level, where decomposition of magnesite is macroscopically apparent, and continue towards the surface of the sample. Iron aspires to enrich especially in the rims. This is probably due to immiscibility of periclase $(\mathrm{MgO})$ and wüstite (FeO) (Boiocchi, et al., 2001) and we suppose that a magnesioferrite component appears in the oxide remains of magnesite.

The zoning of ferropericlase aggregates is most intense in the "hot" part of the wall near the surface. In zone $4 \mathrm{Fe}$ has almost completely migrated from small innermost areas in ferropericlase aggregates (Fig. 3d, Electronic Appendix A: analysis 34). In 


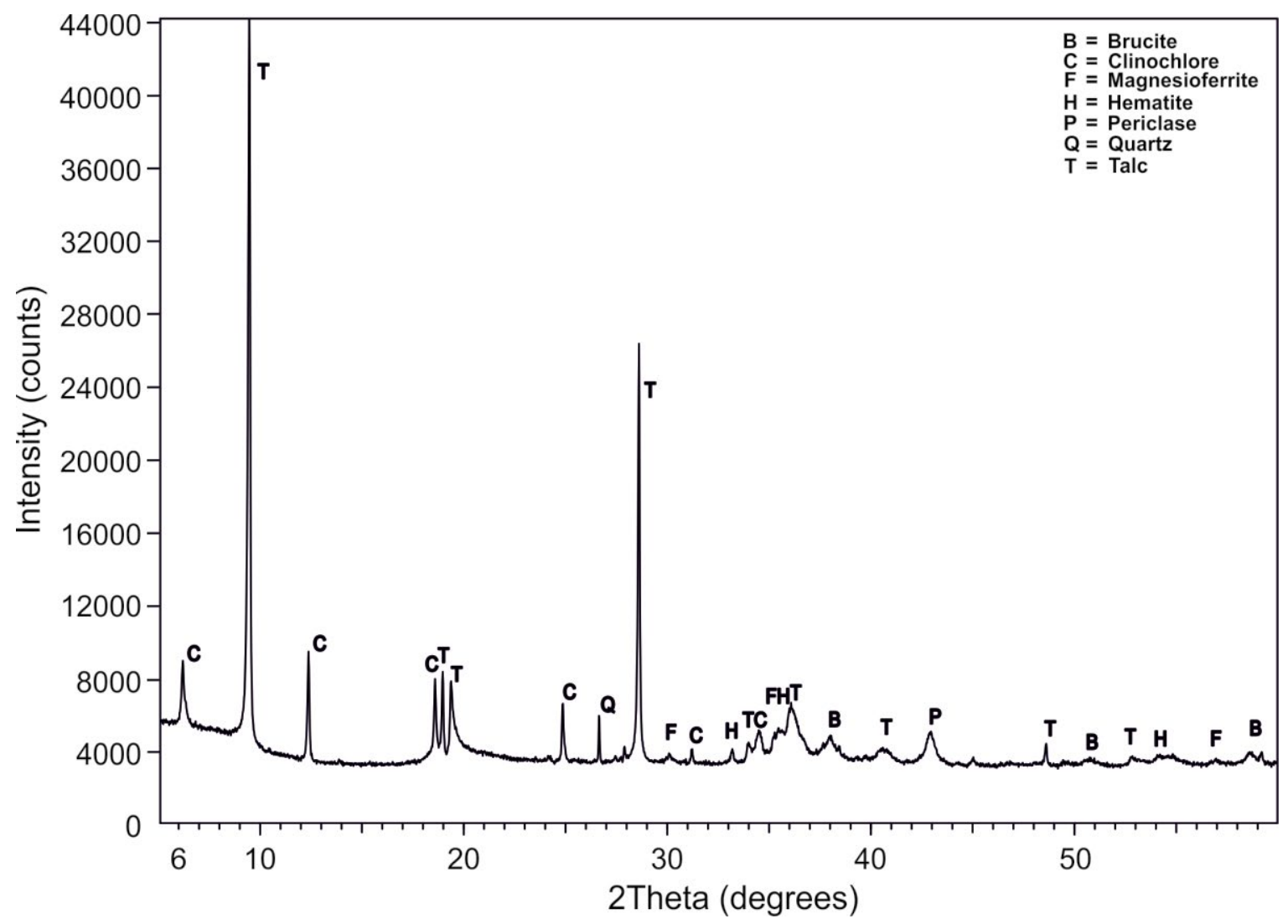

Figure 7. X-ray diffraction pattern of decomposed magnesite soapstone from the surface.

addition, talc rims start to show signs of alteration to a composition corresponding forsterite. The excess $\mathrm{MgO}$ in the alteration product of the rims of talc was most likely originating from the rims of ferropericlase aggregates or former ferromagnesite since they have in average lower $\mathrm{MgO}$ content than in less altered zone 3. Development of the reaction rim on talc is probably one of the hardening supporting factors in the surface area.

$\mathrm{Mg} / \mathrm{Fe}$-ratio of "ferropericlase" aggregate centers compared to their rims in zone 5 (Electronic Appendix A) follows the trend in zone 4 i.e. the $\mathrm{Fe} / \mathrm{Mg}$ ratio is considerably higher in rims. Due to porous structure the rims are misleadingly dark gray in the BSE-image 3e. In addition, here talc rims show signs of alteration to forsterite composition. Excess iron most probably originates from ferromagnesite or ferropericlase according to reactions: $\mathrm{Tc}+5(\mathrm{FeMgs})=4(\mathrm{Fe}$-bearing Fo $)+$
$5 \mathrm{CO}_{2}+\mathrm{H}_{2} \mathrm{O}$; or $\mathrm{Tc}+5(\mathrm{FePer})=4(\mathrm{Fe}$-bearing $\mathrm{Fo})$ $+\mathrm{H}_{2} \mathrm{O}$. Magnetite starts to show loss of iron and addition of silica impurity, so it can be also involved in these reactions (Electronic Appendix A).

As seen in the secondary electron images (Figs. $3 \mathrm{f}$ and $4 \mathrm{~b}$ ), ferropericlase and magnesioferrite are very intimately mixed together, magnesioferrite occurring mostly on the fire chamber side of the aggregates. The ferropericlase/magnesioferrite aggregates are very porous resulting in low totals in their analyses. Moreover, the fine particle size of the sample sets limits to the quality of analytical data.

Due to recurrent periods of high temperature and porous structure in the immediate vicinity of the fire chamber surface, iron has oxidized and magnesioferrite has crystallized in the rims of pseudomorphs after ferromagnesite (Fig. $3 \mathrm{f}$ and Electronic Appendix A). This implies that the mobilization of iron from the central parts towards 


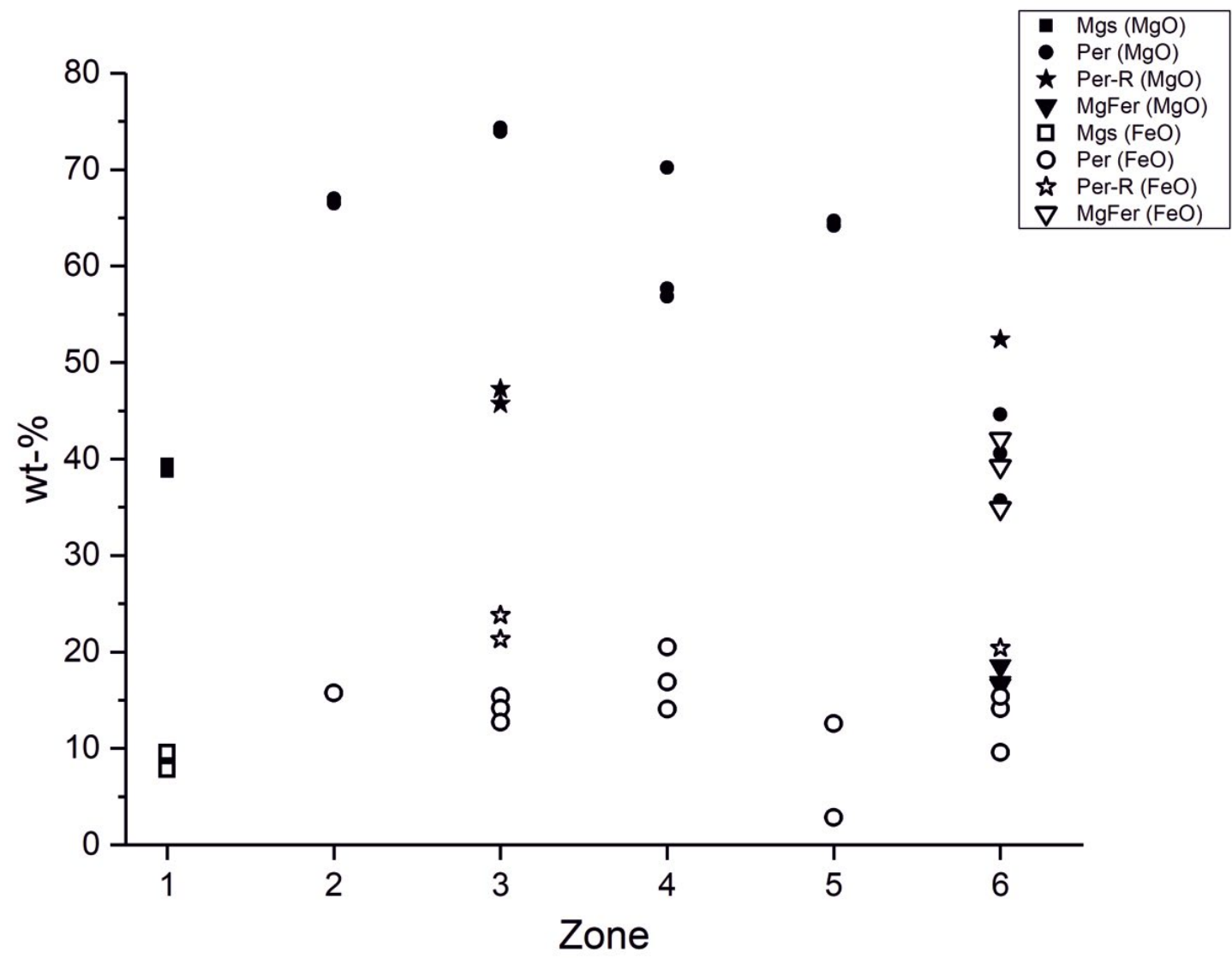

Figure 8. Variation in $\mathrm{FeO}$ and $\mathrm{MgO}$ content from unaltered magnesite of zone 1 (Mgs) to minerals found in the pseudomorphs after magnesite in zones 2-6. Per = periclase, Per-R = analysis from the rim of pseudomorph, MgFer = magnesioferrite.

the surface of pseudomorphs was most intense in this zone (Fig. 8.). The mobilization of iron towards the surface of periclase after heating and especially during slow cooling was already observed by Treffner (1964). According to him, magnesioferrite precipitates near and along the crystal surfaces of periclase grain leaving the interior of periclase iron poor. It is also possible, that magnesioferrite forms by autooxidation simultaneously with the formation of periclase, in an intimate mixture of very small grains where the presence of the two phases would not be possible to deduce by chemical analysis. The evidence of the increase of the content of spinel ferrite on XRD diagrams in zone 2 , immediately after decomposition of magnesite, supports this interpretation, and the fact that magnesioferrite could be recognized by chemical analysis only in the surface zone 6 is probably due to the formation of large enough aggregates of this phase.

It is evident, that the proximity to the surface of the fire chamber enhances the mobilization of iron towards the rims of ferropericlase grains. This agrees with the periclase-wüstite immiscibility study by Boiocchi et al. (2001).

\subsection{Generation of new hydrous magnesium silicate phases}

A magnesium silicate phase was identified in the cracks between talc and pseudomorphs after ferromagnesite (Fig. 4c). It contains almost equal 
amounts (approx. 32 wt.\%) of $\mathrm{MgO}$ and $\mathrm{SiO}_{2}$, and under 10 wt.\% $\mathrm{FeO}^{\text {tot }}$ (analyses 55 and 56, Electronic Appendix A). According to cation ratios, this mineral could be a serpentine group polymorph and probably a result of brucite silicification (Tutolo et al., 2018). The chemical analysis is of poor quality due to the spongy nature of the material.

Chlorite starts to show alteration including potassium enrichment from combustion gases in zone 3 (Fig. 3c, Electronic Appendix A: analyses 15 and 16). As XRD does not show any new phases and the basic pattern of the basal reflections of chlorite does not change significantly up to the surface, we can conclude that the changed chemical composition characterizes still a 2:1 $14 \AA$ layered silicate type derived from chlorite.

\subsection{Volume conservation and brucite formation}

The mass and volume of solid phases reduces considerably when magnesite breaks down to ferropericlase during heating, Ferropericlase aggregates are detached from surrounding minerals, mainly talc. The free space in zones 3 and 4 is often filled with brucite formed due to humidity during subsequent cooling below approx. $270^{\circ} \mathrm{C}$ :

$$
\mathrm{MgO}+\mathrm{H}_{2} \mathrm{O} \rightarrow \mathrm{Mg}(\mathrm{OH})_{2}
$$

It must be noted, that brucite forms in thin layers on the rims of the ferropericlase aggregates and in small microcracks. This texture and concentric zoning of aggregates suggests that the aggregates contracted during the decomposition of ferromagnesite to ferropericlase. Because the temperature of combustion gases may obtain $1200{ }^{\circ} \mathrm{C}$ during heavy burning (Kärki et al., 2013), it is expected that fire chamber was accordingly heated to high temperature and ferropericlase would be stable for considerable time before brucite starts to form during cooling (Thomas et al., 2014). Brucite formation decreases thermal decomposition induced porousness and fills the cracks of the rock. Santos et al. (2016) found, that brucite formation could improve the mechanical properties of refractory castables if there is enough room for the expansive reaction in the microstructure. In magnesite soapstone this space appears to be generated due to volume reduction by ferromagnesite decomposition and a smaller volume of products. Crack-filling brucite may also prevent further transport of elements and gases between the chamber surface and the inner parts of the rock. It should be noted that brucite was not found in zone 6 which is probably due to its thermal instability in the hottest part of the fire chamber wall.

\subsection{Wood combustion}

It can be assumed, that the fireplace from which the samples of this study are taken, has been in an ordinary use of residential wood burning. The material burned in the fire chamber has most probably been mainly birch, pine and spruce as they are the most distributed wood species in Finland (Tomppo et al., 2008). According to Torvela et al. (2014), many types of fine particles are released into respiratory air during biomass combustion processes. Recent studies show that especially zinc is efficiently released from the wood, and particularly birch bark may comprise high contents of zinc and other elements (Misra et al., 1993; Sippula, 2010; Wiinikka et al., 2013). Our data supports the findings of Torvela et al. (2014). As the Electronic Appendix A shows, there are notable concentrations of $\mathrm{ZnO}, \mathrm{K}_{2} \mathrm{O}$ and $\mathrm{SO}_{3}$ in zones 3-6, and lack of those components in zones $1-2$, which are the sections least exposed to combustion gases.

The effects of combustion gases start to show as $\mathrm{K}_{2} \mathrm{O}$-increment in zone 3 (Electronic Appendix A). $\mathrm{K}_{2} \mathrm{O}$ is mainly incorporated in the dehydrated chlorite phase. It is apparent that that a combined action of heat and combustion gases play a crucial role in the transformation of chlorite to a phase much lower in $\mathrm{Oh}$ and enriched in $\mathrm{K}_{2} \mathrm{O}$ (Electronic Appendix A). Talc shows also enrichment in $\mathrm{K}_{2} \mathrm{O}$ in rims and along cleavage planes. The elevation in the content of $\mathrm{K}_{2} \mathrm{O}$ in minerals towards the surface indicates clearly that it is an effect of combustion 
gases coming from the combustion chamber. It is also noteworthy that sulfur has entered the rock, especially into rims of ferropericlase at this level (Williams et al., 2012).

In addition, combustion gases introduce sulfur as well into reaction zones where especially ferropericlase is enriched, already in zone 2. Sulfur is also found in almost all silicate phases of the alteration zones.

The highest $\mathrm{ZnO}$ concentrations have been found in ferropericlase and especially magnesioferrite (MgFer 53. Electronic Appendix A.) in the zone 6. It is expected due to easy incorporation of $\mathrm{Zn}$ in the spinel structure. According to Sippula (2010), natural untreated wood contains approx. 5-210 $\mathrm{mg} \mathrm{Zn} \mathrm{kg}^{-1}$ of dry material. $\mathrm{Zn}$ is released and oxidized in high temperature pyrolysis conditions (Tissari et al., 2015). It can be supposed that its incorporation in magnesioferrite (over $8 \mathrm{wt} . \% \mathrm{ZnO}$ ) contributes to the strengthening of the rock's structure by increasing volume of this mineral. Uski et al. (2015) and Torvela et al. (2014) have concluded that certain metal species in wood combustion, especially $\mathrm{Zn}$, may cause negative health effects via pulmonary route. This has not been studied in this paper, but we suggest more attention should be paid to immobilization of $\mathrm{ZnO}$ in magnesioferrite and other minerals, which might have beneficiary effect by reducing the emission of Zn.

\subsection{Reaction sequence}

Microprobe and XRD-results (Table 3.) reveal that at least following reactions have occurred on or close to the surface of fire chamber wall rock during the residential use of magnesite soapstone fireplace. Due to frequent variation of temperature and humidity conditions, the absolute reaction sequence is partially ambiguous. The italic headline numbering indicates the order in which the reaction sequence have most probably been occurred.

\section{Talc + Ferromagnesite $=$ Enstatite and/or Forsterite} The rims of talc and ferromagnesite reacts together forming enstatite and potentially forsterite. This is shown evidently in Figs. 3a and 3d. There, the sings of talc rim alteration are substantial exclusively near the ferropericlase aggregates. It can be seen in Fig. 3 that alteration of talc also proceeds along cleavage planes. The product phase is either poorly crystalline or volumetrically low (or both) because only traces of enstatite were registered in one of the XRD diagram. The presence of enstatite or forsterite might be hidden by diffraction maxima overlap with the main phases, but only in very small quantities or in the case of poor crystallinity.

\section{Ferromagnesite $=$ Periclase + Magnesioferrite (autoxidation)}

Due to decomposition, ferromagnesite alters to periclase and magnesioferrite with aggregate contraction. Magnesioferrite forms before and/or simultaneously with ferropericlase in autoxidation reaction with decomposition gases of talc and ferromagnesite. The other, less likely alternative for magnesioferrite formation is that the oxidation occurs due to combustion gases.

\section{Talc $=$ Enstatite + Quartz}

Thermal decomposition of talc leads to formation of enstatite and quartz.

\section{3. $\mathrm{Fe}-\mathrm{Mg}$ mobilization in Periclase / Magnesioferrite- aggregates}

Iron tends to move towards the rims in $\mathrm{Mg}$-Fe-oxide aggregates leaving composition of centers closer to pure periclase. This reaction may also start to occur immediately after the first Tc + FeMgs-reaction.

\section{2, 3, 4. Brucite formation}

Brucite may form in any stage after the first reaction due to slow cooling. 


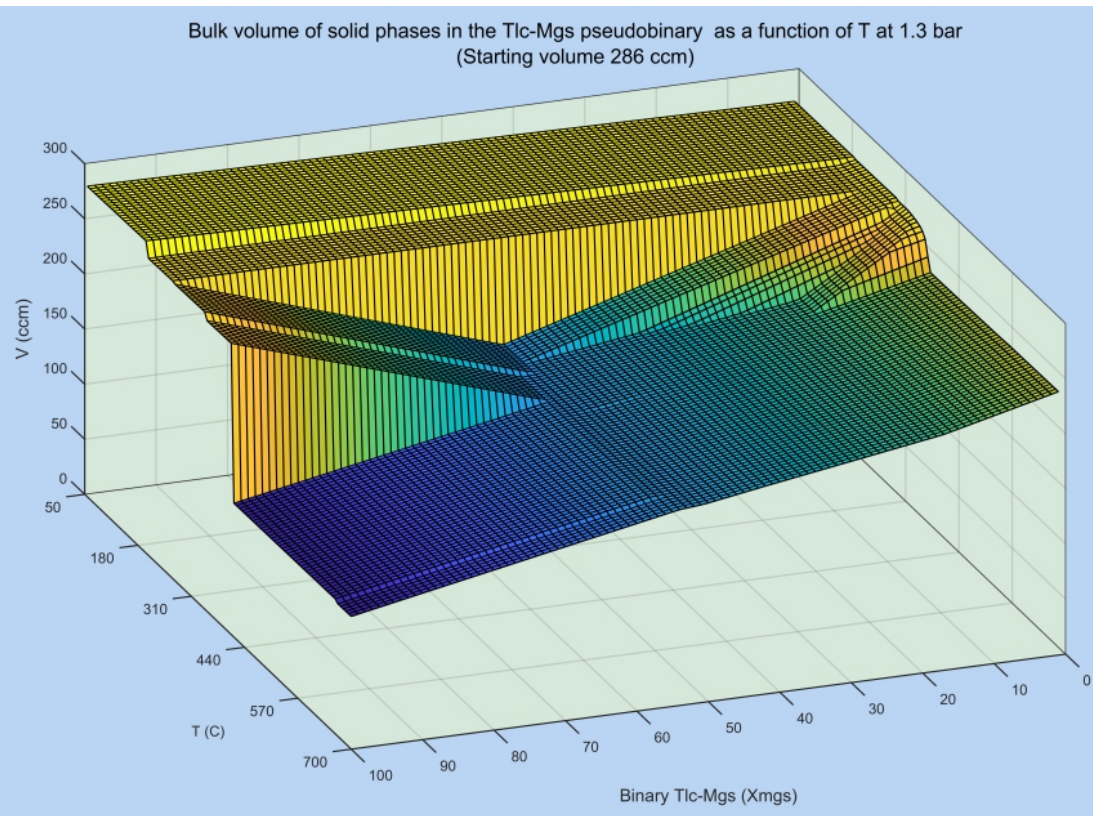

Figure 9. Diagram showing the bulk volume loss of solids in a talc-magnesite pseudobinary during heating from 50 to $700{ }^{\circ} \mathrm{C}$ at 1.3 bar, assuming the reactions are completed, and the system reached equilibrium.

\section{(1), 2, 3, 4. Zn and Kaddition}

Combustion gases transport zinc and potassium into ferropericlase and magnesioferrite $(\mathrm{Zn})$ and into chlorite and talc rims $(\mathrm{K})$, respectively. Addition of $\mathrm{K}$ is accompanying the dehydration of chlorite. These addition reactions may also occur in any stage after the first reaction or even before the decomposition reactions at the surface on the fire chamber side.

\subsection{Parameters affecting the rock's durability}

The cooperative effect of the following, debilitating and strengthening parameters determines the quality and durability of magnesite soapstone, which is used as a construction material in fire chamber walls. The structure-destroying parameters are ferromagnesite decarbonation, talc dehydroxylation and volume loss caused by volatile loss reactions (Fig. 9).
The parameters that increase rock's durability can be divided into two effects:

\section{Volume increasing parameters that compensate the} volume loss:

- Hydration as in form of brucite formation. Brucite forms into microcracks surrounding and penetrating ferropericlase aggregates.

- Further serpentinization of brucite near the fire chamber side alters the rock's structure into a denser form.

- In addition, the formation of $\mathrm{Zn}$-rich oxides and change in the composition of phyllosilicates due to inclusion of elements $(\mathrm{Zn}$ and $\mathrm{K}$ ) from combustion gases increases the volume of the solid phases.

\section{Rock hardening parameters:}

- Anhydrous silicate formation due to thermal decomposition of talc and reaction between talc and magnesite and increase the density of solids (Fig. 10). 


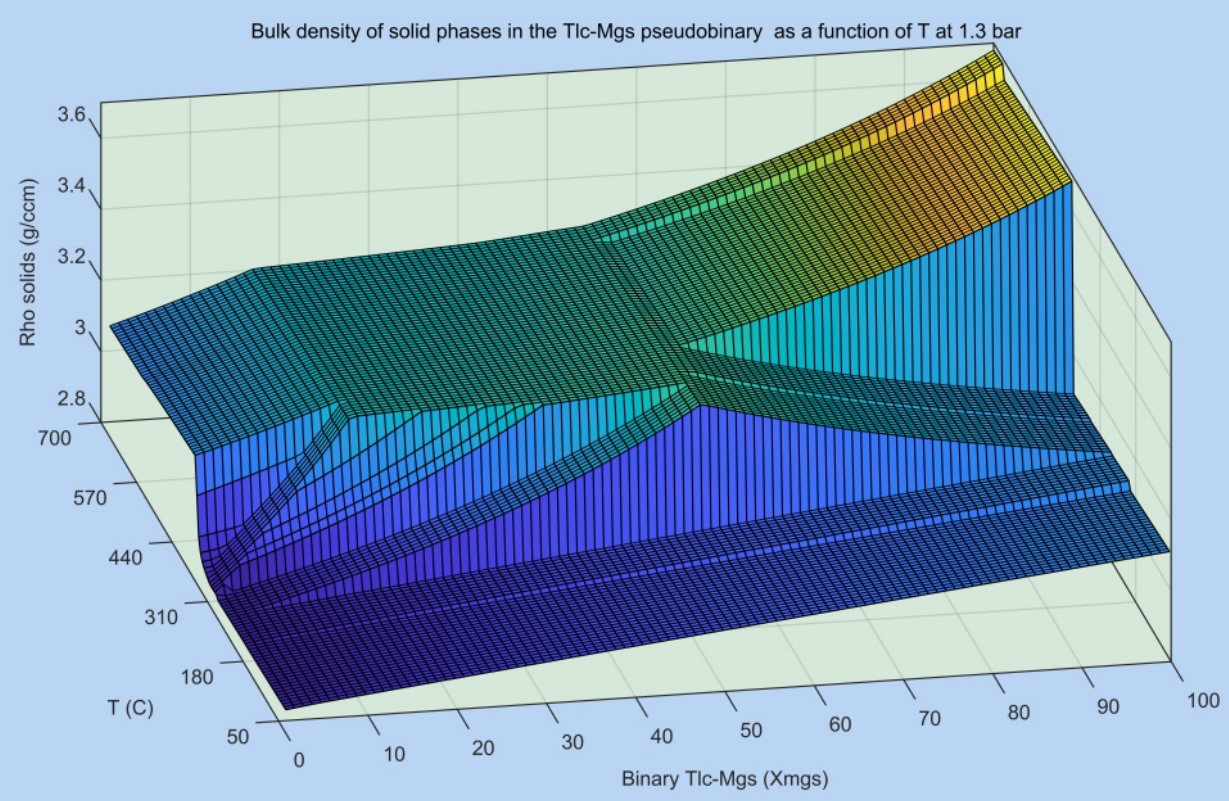

Figure 10. Diagram showing the bulk increase of the density of solids in a talc-magnesite pseudobinary during heating from 50 to $700{ }^{\circ} \mathrm{C}$ at $1.3 \mathrm{bar}$, assuming the reactions are completed, and the system reached equilibrium.

- $\mathrm{Mg}$-Fe oxide formation as alteration product of ferromagnesite. Being denser and harder, the Mg-Fe oxides hardens the surface of fire chamber rock. The recrystallization processes of $\mathrm{Mg}$-Fe oxides might also contribute to better mechanical stability of the rock.

- An additional contribution to the hardening of the rock might be the transformation of chlorite into a less hydrous form with inclusion of additional cations ( $\mathrm{K}$ and $\mathrm{Zn}$ ) that is most probably decreasing its plasticity.

In general, due to conditions that have prevailed in fire chamber for decades, the composition of fire chamber wall rock surface has altered to a more refractory type (olivine-enstatite-magnesium-ironoxide) direction (Kelvin et al., 2010; Szczerba et al., 2013; Behera \& Sarkar, 2015; Chen et al., 2016).

Talc and carbonates are soft minerals, but form together with one or multiple foliations resilient and almost reticular structure. For instance, the talc rims altered to enstatite, although small in volumes, cover a large surface area responsible for the rheological properties of material. They are harder than unaltered talc and probably have better attachment to other components of the rock contributing to the stability of the structure. On the other hand, the center of talc is flexible and can slightly adapt to size changes of adjacent minerals if needed. This also assists the altered surface to stay in place and not detach from the fire chamber wall during heating.

\section{Conclusions}

Hardness and durability of magnesite soapstone surface subjected to fire chamber conditions increases over time. Based on the electron probe microscopy and the X-ray diffraction data, we can conclude that the hardening is due to following decomposition and alteration related developments in chemical composition of minerals and in microstructure:

- Ferromagnesite decomposition and alteration to periclase and magnesioferrite. 
- Brucite formation due to hydration in of periclase in microcracks.

- Serpentinization of brucite

- Alteration of talc rims to anhydrous $\mathrm{Mg}$ silicate.

- Resilient nature of talc contributes to the durability of magnesite soapstone.

- Iron mobilization from center towards the rims of $\mathrm{Mg}$-Fe oxide aggregates.

- $\mathrm{Zn}$ and $\mathrm{K}$ addition from combustion gases to magnesioferrite $(\mathrm{Zn})$ and dehydrated chlorite and talc rims.

\section{Acknowledgements}

This research was supported by K.H. Renlund Foundation, Fund for Quality Improvement of Building Products and Juhani Lehikoinen Foundation, which all are gratefully acknowledged. We thank also Pentti Hölttä and Heikki Pirinen for their useful and constructive comments.

\section{Supplementary data}

Electronic Appendix A for this article is available via Bulletin of the Geological Society of Finland web page.

Huhta, A., Kärki, A. \& Hanski, E., 2016. A new method for testing thermal shock resistance properties of soapstone - Effects of microstructures and mineralogical variables. Bulletin of the Geological Society of Finland 88, 21-46. https://doi.org/10.17741/bgsf/88.1.002

Kärki, A., Havela, T., Huhta, A., Jokinen, J.U.S. \& Pohjola, S., 2013. VUKEII-tutkimuskonsortio. Vuolukiven kestävä käyttö, Osa II, Vuolukiven materiaaliominaisuudet, Loppuraportti, Tekes- the Finnish Funding Agency for Innovation, pp. 34-140. (in Finnish)

Kelvin, H., Ramesh, S., Tan, C.Y. \& Teng, W.D., 2010. Phase analysis and densification of steatite-based ceramics. International Journal of Automotive and Mechanical Engineering 1,38-45. https://doi.org/10.15282/ijame.1.2010.4.0004

Misra, M.K., Ragland, K.W. \& Baker, A.J., 1993. Wood ash composition as a function of furnace temperature. Biomass \& Bioenergy 4, 103-116. https://doi.org/10.1016/0961-9534(93)90032-Y

Santos, T.Jr., Luz, A.P., Pagliosa, C. \& Pandolfelli, V.C., 2016. $\mathrm{Mg}(\mathrm{OH})_{2}$ Nucleation and growth parameters applicable for the development of MgO-based refractory castables. Journal of American Ceramic Society 99, 461-469. https://doi.org/10.1111/jace.14019

Sippula, O., 2010. Fine particle formation and emissions in biomass combustion. PhD Thesis. University of Eastern Finland, Finland. Report series in aerosol sciences. 108, $64 \mathrm{p}$.

Storemyr, P., 2004. Weathering of soapstone in a historical perspective. Materials Characterization 53, 191-207. https://doi.org/10.1016/j.matchar.2004.06.015

Storemyr, P. \& Heldal, T., 2002. Soapstone production through Norwegian history: Geology, properties, quarrying and use. In: Herrman, J., Herz, N. \& Newman, R. (eds.): 
ASMOSIA 5, Interdisciplinary studies on ancient stone - proceedings of the Fifth international conference of the association for the study of marble and other stones in antiquity, Museum of Fine Arts, Boston, June $11^{\text {th }}-15^{\text {th }}$, 1998. London: Archetype Publications, pp. 359-369.

Szczerba, J., Prorok. R., Śnieżek, E., Madej, D. \& Maślona, K., 2013. Influence of time and temperature on ageing and phases synthesis in the $\mathrm{MgO}-\mathrm{SiO}_{2}-\mathrm{H}_{2} \mathrm{O}$ system. Thermochimica Acta 567, 57-64. https://doi.org/10.1016/j.tca.2013.01.018

Thomas, J.J., Musso, S. \& Prestini, I., 2014. Kinetics and activation energy of magnesium oxide hydration. Journal of American Ceramic Society 97, 275-282. https://doi.org/10.1111/jace.12661

Tissari, J., Sippula, O., Torvela, T., Lamberg, H., Karhunen, T., Paukkunen, S., Hirvonen, M.-R. \& Jokiniemi, J., 2015. Zinc nanoparticle formation and physicochemical properties in wood combustion - Experiments with zincdoped pellets in a small-scale boiler. Fuel 143, 404-413. https://doi.org/10.1016/j.fuel.2014.11.076

Tomppo, E., Haakana, M., Katila, M. \& Peräsaari, J., 2008. Multi-source national forest inventory: Methods and applications. Springer Science + Business Media B. V., $373 \mathrm{p}$. https://doi.org/10.1007/978-1-4020-8713-4

Torvela, T., Tissari, J., Sippula, O., Kaivosoja, T., Leskinen, J., Virén, A. \& Lähde, A., 2014. Effect of wood combustion conditions on the morphology of freshly emitted fine particles. Atmospheric Environment 87, 65-76.

https://doi.org/10.1016/j.atmosenv.2014.01.028

Treffner, W.S., 1964. Microstructure of periclase. Journal of American Ceramic Society 47, 401-409. https://doi.org/10.1111/j.1151-2916.1964.tb13841.x

Tutolo, B.M., Luhmann, A.J., Tosca, N.J. \& Seyfried Jr.,W.E., 2018. Serpentinization as a reactive transport process: The brucite silicification reaction. Earth and Planetary Science Letters 484, 385-395. https://doi.org/10.1016/j.epsl.2017.12.029

Uski, O., Jalava, P.I., Happo, M.S., Torvela, T., Leskinen, J., Mäki-Paakkanen, J., Tissari, J., Sippula, O., Lamberg, H., Jokiniemi, J. \& Hirvonen, M.-R., 2015. Effect of fuel zinc content on toxicological responses of particulate matter from pellet combustion in vitro. Science of the Total Environment 551, 331-340. https://doi.org/10.1016/j.scitotenv.2014.12.061

Wiinikka, H., Grönberg, C. \& Boman, C., 2013. Emissions of heavy metals during fixed-bed combustion of six biomass fuels. Energy \& Fuels. 27, 1073-1080. https://doi.org/10.1021/ef3011146

Williams, A., Jones, J., Ma, L. \& Pourkashanian, M., 2012. Pollutants from the combustion of solid biomass fuels. Progress in Energy and Combustion Science 38, 113-137. https://doi.org/10.1016/j.pecs.2011.10.001 